\title{
Compaction Property Of Integrated Backfilling Materials
}

\author{
FanXiang ${ }^{1, \mathrm{a}}$, Facheng $\mathrm{Yi}^{2, \mathrm{~b}}$, Defu $\mathrm{Du}^{3, \mathrm{c}}$, Xuemei Zhang ${ }^{1}$
}

1. Tian Fu College of Southwestern University of Finance and Economics, Sichuan, China

2. Southwest University of Science \& Technology, Mianyang, Sichuan, China

3. Southwest Oil and Gas Field Sichuan Public Affairs Management Center ,Sichuan, China

a920391362@qq.com, b504539179@qq.com, c 53273097@qq.com

Keywords: bentonite, bentonite, zeolite, maximum dry density, optimum moisture content

Abstract : Nuclear industry production would produce large amounts of nuclear waste.How to safely dispose of the nuclear waste especially high level radioactive waste (HLW) became increasingly serious problem at present. This article turned out that compaction energy was an important factor of the impact compaction performance through the light and heavy compaction experiments. Adding a certain amount zeolite or attapulgite could get larger maximum dry density and smaller optimal moisture content. In zeolite or attapulgite added to $0 \%-20 \%$ of dry density increased mixed materials, compaction curve was relatively tame. With zeolite or attapulgite increased to $20 \%$ to $50 \%$, the pressure increased sharply. But when zeolite or attapulgite increased more than $50 \%$,the pressure of the compaction needed higher. Thus the content of zeolite or attapulgite in $20 \%$ to $30 \%$ was easier to compact.

\section{Introduction}

In order to relieve the effect of the pressure of the surrounding rock on the waste cans in the geological repository of high-level radioactive waste, the gap between the surrounding rock and the waste tank were closed effectively block the leakage of radioactive waste material to the environment. A buffer/backfill material must be filled between surrounding rock and the waste tank ${ }^{[1]}$. It was as the last artificial barrier in the repository of high level waste disposal, needed the function of the engineering barrier, the function of the hydraulic barrier, chemical barrier and thermal conductivity. In deep geological disposal, the heat released by the nuclear waste diffused back to the backfill material, which would be subjected to high temperatures, high stresses and strong air currents, may create fissures. Then groundwater was dipped into the backfill material along the fracture. Furthmore, the untreated bentonite was difficult to meet the performance requirements of the high-level waste repository. It must be treated and compacted before it could be used as buffer / backfill material. The compaction properties of high compacted backfill materials were studied in China. Most of them were single bentonite or sand mixture.So it was necessary to study the compaction properties of the composites. The compaction experiments in this paper focused on the relationship between the maximum dry density and the optimal moisture content under different compaction energy (light and heavy) of $\mathrm{ZB}$ and $\mathrm{AB}$ mixtures.

\section{Experiment}

\section{Sample}

Raw materials used in the experiment were Xinjiang Altai bentonite $(\mathrm{Na}+)$, Xinjiang zeolite, Sichuan Jiangyou pyrite . Xinjiang Altai bentonite was light gray and white. Its deposit was located 
in the northern edge of Xinjiang Junggar Basin. The main mineral of bentonite in Xinjiang Altai was $\mathrm{Na}$ - montmorillonite, and its content was high and contained a small amount of $\alpha$ - quartz. Since it had good cation exchange capacity, Expansion properties in this experiment, so it was as the substrate of the experiment. The physico-chemical and engineering properties of bentonite in Xinjiang are refered with table 1.

Tab. 1 The Physico-chemical and Engineering Index of Xinjiang Bentonite

\begin{tabular}{|c|c|c|c|c|c|c|}
\hline $\begin{array}{l}\text { Swelling } \\
\text { Capacity } \\
(\mathrm{mL} / 1 \mathrm{~g})\end{array}$ & $\begin{array}{l}\text { Swelling } \\
\text { Value } \\
(\mathrm{mL} / 3 \mathrm{~g})\end{array}$ & $\mathrm{pH}$ & $\begin{array}{c}\text { Absorption of } \\
\text { Blue } \\
\text { (Meq/100g) }\end{array}$ & $\begin{array}{c}\text { CEC } \\
(\mathrm{mmol} / 100 \mathrm{~g})\end{array}$ & $\begin{array}{c}\text { Liquid } \\
\text { Limit }(\%)\end{array}$ & $\begin{array}{c}\text { Plastic Limit } \\
\qquad(\%)\end{array}$ \\
\hline 28 & 42 & 6.4 & 139 & 82 & 82.3 & 27 \\
\hline $\begin{array}{c}\text { Dry } \\
\text { Moisture } \\
\text { Content }\end{array}$ & $\begin{array}{c}\text { Bulk } \\
\text { Density } \\
\left(\mathrm{g} / \mathrm{cm}^{3}\right)\end{array}$ & Proportion & $\begin{array}{l}\text { Dry Density } \\
\left(\mathrm{g} / \mathrm{cm}^{3}\right)\end{array}$ & Porosity (\%) & $\begin{array}{c}\text { Plasticity } \\
\text { Index }\end{array}$ & $\begin{array}{c}\text { Thermal } \\
\text { Conductivity } \\
\left(\mathrm{w} / \mathrm{m} \cdot{ }^{\circ} \mathrm{C}\right)\end{array}$ \\
\hline 14.47 & 2.23 & 2.52 & 1.89 & 24.10 & 51.1 & 0.21 \\
\hline
\end{tabular}

Xinjiang zeolite was mainly plate, sheet, needle. From the X-ray diffraction test, it was found that the main mineral composition of the zeolite was mordenite, clinoptilolite, zeolite, quartz, montmorillonite, feldspar and hydrous mica. Because the CEC value of zeolite( $98 \mathrm{mmol} / 100 \mathrm{~g})$ was much higher than that of Xinjiang bentonite ore, it showed that the cation exchange capacity of the zeolite was better than that of Xinjiang bentonite. But zeolite had porous characteristics, poor water barrier, and needed to add bentonite to prevent groundwater into the waste container tank.It also needed to prevent the radionuclide with the groundwater migration, diffusion.

The cation exchange capacity of attapulgite was $0.295 \mathrm{mmol} / \mathrm{g}$, which was smaller than that of bentonite and zeolite. The porosity was larger and the thermal conductivity $\left(0.277 \mathrm{~W} / \mathrm{m} \cdot{ }^{\circ} \mathrm{C}\right)$ was the biggest, which was mainly due to the higher siliceous content. According to previous studies ${ }^{[2]}$, attapulgite for some nuclides such as cesium adsorption performance was better than bentonite, and easy expansion properties of water was good, so this article also tried to explore the attapulgite as one of the candidate materials to optimize integrated backfill material.

Backfill material into the ground a few kilometers, the release of radionuclide energy was difficult to heat out from the waste filling, and pyrite had a good thermal conductivity to solve this problem.Therefore, according to the complementary properties of different mineral materials, depending a certain combination ratio on better developing the superior performance of the there materials to achieve optimal integration. According to the pre-required dry density and moisture content of the sample configuration, several natural samples were naturally air-dried, crushed into 100 mesh, bentonite, zeolite (or attapulgite), pyrite (additive) mixed by a certain proportion. A few groups of backfill materials are found in Table 2.

Tab.2 Composite Mineral Constituent Content

\begin{tabular}{|c|c|c|c|c|c|}
\hline $\begin{array}{c}\text { Name of } \\
\text { the mineral }\end{array}$ & $\begin{array}{c}\text { Zeolite } \\
\text { content }(\%)\end{array}$ & $\begin{array}{c}\text { Bentonite } \\
\text { content }(\%)\end{array}$ & $\begin{array}{c}\text { Name of } \\
\text { the mineral }\end{array}$ & $\begin{array}{c}\text { Attapulgite } \\
\text { content (\%) }\end{array}$ & Bentonite \\
content (\%)
\end{tabular}

Note: The compound mineral No. $\mathrm{Z}_{5} \mathrm{~B}_{5}$ stand for Zeolite was $50 \%$ of the total mass mixture(zeolites and bentonite), which was added $10 \%$ of pyrite as an additive. A-Attapulgite, B-Bentonite, Z- Zeolite ,P - Pyrite, the rest of the ratio and so on. 


\section{Experimental facilities}

Compaction equipment was DJS-2 type digital display standard electric compaction instrument producted in Nanjing Soil Instrument Factory. Light and heavy compaction test compaction instrument main components specifications were refered with Table 3. Stripping equipment used DTM-2 automatic stripping machine was producted in Nanjing soil instrument production. Oven and dryer were DZ-1BC type, Tianjin Tester Instrument Ltd. The others were balance ,round hole screen, metal plate, Soil shovel, Disc, bulb, bulldozer, aluminum box, ring knife, earth knife, Vaseline, dial indicator and so on.

Tab.3 The Standard of Compaction Apparatus

\begin{tabular}{|c|c|c|c|c|c|c|c|}
\hline \multirow[b]{2}{*}{$\begin{array}{c}\text { Test } \\
\text { method }\end{array}$} & \multirow[b]{2}{*}{$\begin{array}{l}\text { Hammer } \\
\text { Diamete-r } \\
(\mathrm{mm})\end{array}$} & \multirow[b]{2}{*}{$\begin{array}{c}\text { Heavy } \\
\text { hammer } \\
(\mathrm{kg})\end{array}$} & \multirow[b]{2}{*}{$\begin{array}{l}\text { High fall } \\
(\mathrm{mm})\end{array}$} & \multicolumn{3}{|c|}{ The compaction cylinder } & \multirow[b]{2}{*}{$\begin{array}{l}\text { Protecting tube } \\
\text { height }(\mathrm{mm})\end{array}$} \\
\hline & & & & $\begin{array}{c}\text { Inner } \\
\text { diameter } \\
(\mathrm{mm})\end{array}$ & $\begin{array}{l}\text { Tube of } \\
\text { high } \\
(\mathrm{mm})\end{array}$ & $\begin{array}{l}\text { volume } \\
\left(\mathrm{cm}^{3}\right)\end{array}$ & \\
\hline Light & 51 & 2.5 & 305 & 102 & 116 & 947.4 & 50 \\
\hline Heavy & 51 & 2.5 & 457 & 152 & 116 & 2103.9 & 50 \\
\hline
\end{tabular}

\section{Dynamic compaction test method}

In this paper, lightweight and heavy-duty experiments carried out on backfill material mixture of different proportions were studied. We needed to put the material over the $5 \mathrm{~mm}$ screen and they were dried under $105^{\circ} \mathrm{C}$ to get constant weight. Then each sample was added to a certain distilled water and sealed for 24 hours by the spray method, and t each ratio was formulated with 5 diferent water contents. The water content of the backfill material was reduced by $2 \%$. In the light compaction test, the soil sample under the electric hammer was divided into three times, each time 25 times, and the sample was divided into 5 layers, 56 times/layer in heavy compaction. Finally, the sample was introduced into the cylinder, and the water content of the sample was measured from the center of the sample, and the water content was calculated to $0.1 \%$. We could draw the curve of the relationship between dry density and water content and got the maximum dry density and the most water content through the curve. That was the maximum dry density of the corresponding was optimal moisture content. The dry density of each point after compaction was calculated as follows :

$$
\rho_{d}=\frac{\rho}{1+0.01 w}
$$

$\rho_{\mathrm{d}}$ - $\operatorname{dry}$ density $\left(\mathrm{g} / \mathrm{cm}^{3}\right)$, calculated to $0.01, \rho$-wet density $(\mathrm{g} / \mathrm{cm} 3)$, w-water content $(\%)$

\section{Experimental results and discussion}

\section{Effect of Bentonite Proportion}

Through the table4, Fig.1, Fig.2, it was showed that with the decrease of bentonite content, the maximum dry density increased and the optimal water content decreased. In this paper, the dry density of a single mineral Xinjiang Altai bentonite maximum was $1.271 \mathrm{~g} / \mathrm{cm} 3$, the optimum moisture content of $42.96 \%$. Abidin ${ }^{[3]}$ and other studies had shown that the bentonite content of $3 \%$ 
$-20 \%$, with the bentonite content increased, the optimal moisture content increased, the maximum dry density decreased.

Kayabali ${ }^{[4]}$ and Hou Li ${ }^{[5]}$ also studied the compaction properties of $\mathrm{ZB}$ mixtures. The results showed that the optimal water content decreased with the increase of bentonite content in the same compaction work. The conclusion was opposite to the results in this paper. Theoretically, under the same compaction energy, soil particles after expansion would increase due to the water absorption of more bentonite. But the maximum dry density should be reduced, and the optimal moisture content should be increased. It Indicated that the more bentonite soil content was, the more difficult compaction was. In this paper, adding a certain amount of zeolite or attapulgite could make the plasticity index of backfill material significantly reduce, and plasticity reduce. The compaction test could achieve greater maximum dry density and smaller optimal moisture content, thus we could get a clear peak compaction curve though original pure bentonite nature of "conditioning" was improved.

Tab.4 The dry density and water content of $\mathrm{ZB}$ and $\mathrm{AB}$ mixture under the low compaction

\begin{tabular}{cccccc}
\hline Sample & Water Content $(\%)$ & Dry density $\left(\mathrm{g} / \mathrm{cm}^{3}\right)$ & Sample & Water Content $(\%)$ & Dry density $\left(\mathrm{g} / \mathrm{cm}^{3}\right)$ \\
\hline $\mathrm{Z}_{5} \mathrm{~B}_{5}$ & 31.27 & 1.52 & $\mathrm{~A}_{5} \mathrm{~B}_{5}$ & 36.72 & 1.42 \\
\hline $\mathrm{Z}_{3} \mathrm{~B}_{7}$ & 35.55 & 1.38 & $\mathrm{~A}_{3} \mathrm{~B}_{7}$ & 38.43 & 1.32 \\
\hline $\mathrm{Z}_{2} \mathrm{~B}_{8}$ & 37.79 & 1.31 & $\mathrm{~A}_{2} \mathrm{~B}_{8}$ & 40.88 & 1.28 \\
\hline $\mathrm{Z}_{0} \mathrm{~B}_{10}$ & 42.96 & 1.27 & $\mathrm{~A}_{0} \mathrm{~B}_{10}$ & 42.45 & 1.26 \\
\hline
\end{tabular}

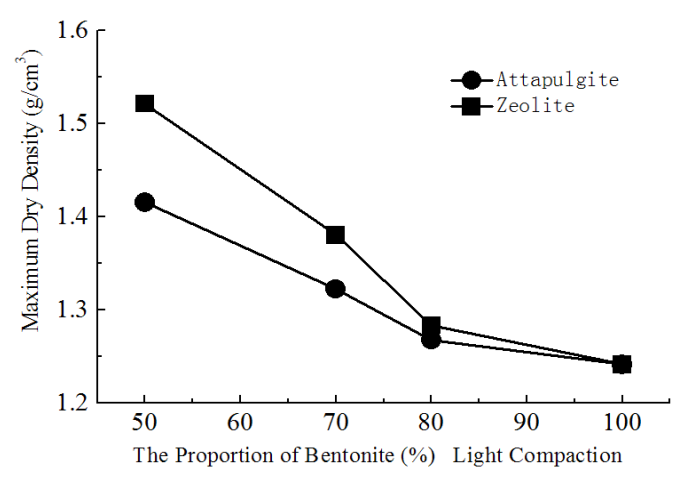

Fig.3 The maximum dry density of different materials under the low compaction

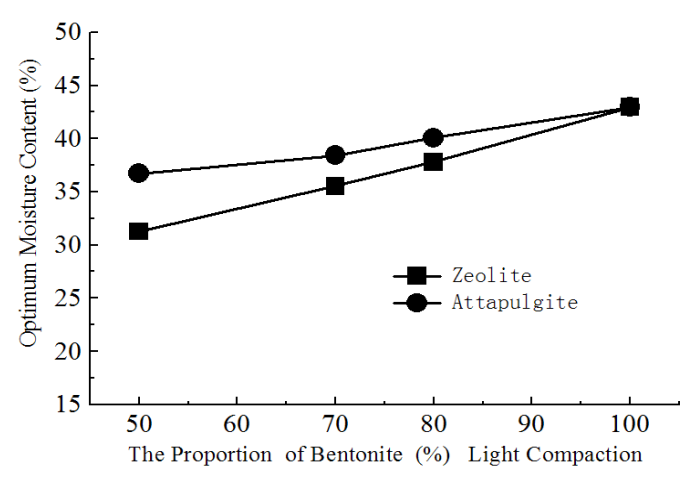

Fig .4 The optimum moisture content of different materials under the low compaction

\section{Influence of compaction energy}

From tab4, tab5, fig.3 and fig.4, we also could see that the dry density of the mixed material obtained by the heavy compaction was larger than that of the light compact. Therefore, compaction energy was an important factor affecting the compaction effect of composite minerals. It was worth noting that when the zeolite or attapulgite was added in the range of $0 \%$ to $20 \%$, the dry density of the mixed material increased little and the compaction curve was relatively gentle. When the zeolite or attapulgite was increased to $20 \%-50 \%$, the compacted dry density increased sharply. It was because the mixture of bentonite accounted for most of the composition, which had large surface area, water absorption capacity, strong combination of water film changes in the scope of large. Then, in the external force, the particles moved not only to overcome the friction resistance within the zeolite and bentonite or attapulgite, but also overcomed by the water molecules cohesion. So the compaction range of the mixture was large and the relative change of the dry density was relatively small. However, the addition of $50 \%$ zeolite or attapulgite had a high dry density, which was difficult to control with light or heavy compaction during the actual construction, and the 
construction time was long.

Tab.5 The dry density and water content of $\mathrm{ZB}$ and $\mathrm{AB}$ mixture under the heavy compaction

\begin{tabular}{cccccc}
\hline Sampl & Water Content $(\%)$ & Dry density $\left(\mathrm{g} / \mathrm{cm}^{3}\right)$ & Sample & Water Content $(\%)$ & Dry density $\left(\mathrm{g} / \mathrm{cm}^{3}\right)$ \\
\hline $\mathrm{Z}_{5} \mathrm{~B}_{5}$ & 30.77 & 1.73 & $\mathrm{~A}_{5} \mathrm{~B}_{5}$ & 32.77 & 1.64 \\
\hline $\mathrm{Z}_{3} \mathrm{~B}_{7}$ & 32.76 & 1.63 & $\mathrm{~A}_{3} \mathrm{~B}_{7}$ & 34.95 & 1.52 \\
\hline $\mathrm{Z}_{2} \mathrm{~B}_{8}$ & 35.79 & 1.48 & $\mathrm{~A}_{2} \mathrm{~B}_{8}$ & 36.88 & 1.45 \\
\hline $\mathrm{Z}_{0} \mathrm{~B}_{10}$ & 40.22 & 1.41 & $\mathrm{~A}_{0} \mathrm{~B}_{10}$ & 40.22 & 1.41 \\
\hline
\end{tabular}

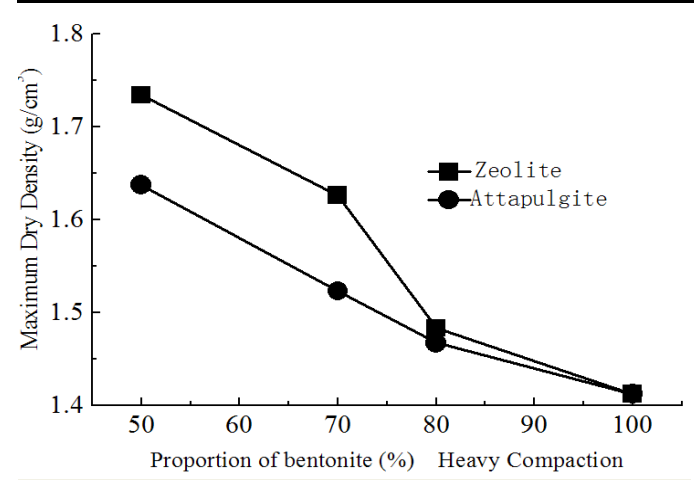

Fig.3 The maximumu dry density of different materials under the heavy compaction

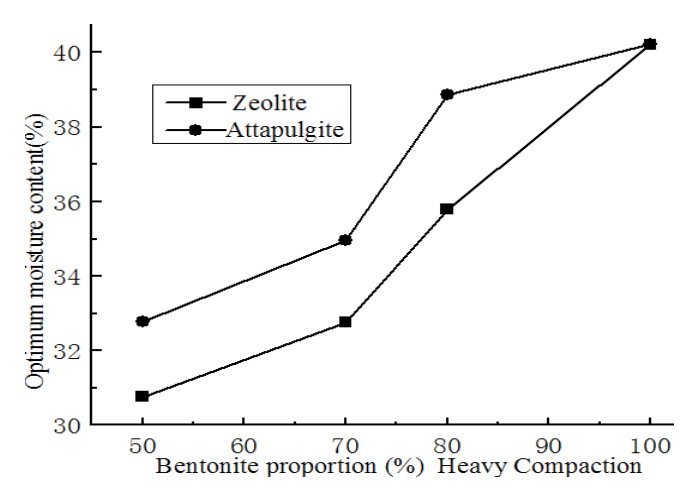

Fig .4 The optimum moisture content of different materials under the heavycompaction

From Fig. 1, Fig. 2, Fig. 3 and Fig.4, it could be seen that the maximum dry density of the ZB composite minerals under light and heavy compaction conditions was larger than that of the $\mathrm{AB}$ composite minerals, and the optimum moisture content was less than that of the $\mathrm{AB}$ composite minerals. In the same compaction power, a certain ratio of adding zeolite was easier to get a dry density of the larger minerals than the addition of attapulgite.

\section{Conclusion}

The compaction experiments in this paper focused on the relationship between the maximum dry density and the optimal moisture content under different compaction work (light and heavy) of ZB and $\mathrm{AB}$ mixtures. The experimental results showed that adding a certain amount of zeolite or attapulgite could work out that the plasticity index of backfill material was obviously reduced and the plasticity was reduced. However, the maximum dry density and the smaller optimum moisture content could be obtained in the compaction test. The original bentonite was difficult to be "conditioned", and the peak could be obtained obvious compaction curve.In addition, the dry density of the mixed material obtained by the heavy compacting was larger than that of the light compaction. Therefore, compaction energy was an important factor affecting the compaction effect of composite minerals. Overdose attapulgite or zeolite aggregated particles easily slide in the frame.It was difficult to obtain a higher maximum dry density even if too much high load. The results of dynamic compaction was the same, so the content of attapulgite or zeolite of $20 \%-30 \%$ easier to compact. 


\section{Acknowledgements}

This work was financially supported by the nation basic defense research project of Professor Facheng Yi ( A3120080126 )

\section{References}

[1] Zhou Kanghan,in: Hydrogenation and Expansion of High Compaction Cushioning Materials and the Rule of Radionuclide Migration [PhD Thesis], edtied by Beijing: Tsinghua University. (1995), p. 667

[2] YI Fa-Cheng, LI Yu-Xiang, QIAN Guang-Ren, et al. in: Study on Adsorption of Low and Intermediate Radionuclides $\mathrm{Sr}$ and $\mathrm{Cs}$ from Attapulgite Clay, edtied by Progress in Mineral Resources Utilization, Forum Vol. (1) 16-20 (2002)

[3] Abidin Kaya,Seda Durukan. in:Utilization of bentonite-embedded zeolite as clay liner , edtied by Applied Clay Science,Vol.(25 ) 83-91 (2004)

[4] Kayabal1,K. in:Engineering aspects of a novel landfill material: bentonite amended natural zeolite, edtied by Engineering Geology, Vol. (46) 105-114 (1997)

[5] Hou Li: Backfill material optimization and its performance integration (Southwest University of Science and Technology, China .2008) 